\title{
Anthropometric parameters and their relationship to serum growth hormone-binding protein and leptin levels in children with acute lymphoblastic leukemia: a prospective study
}

\author{
B Argüelles, V Barrios, M Buño, L Madero ${ }^{1}$ and J Argente \\ Universidad Autónoma, Department of Pediatrics, Division of Pediatric Endocrinology and ${ }^{1}$ Division of Pediatric Oncology, \\ Hospital Universitario Niño Jesús, E-28009 Madrid, Spain \\ (Correspondence should be addressed to J Argente, Division of Pediatric Endocrinology, Hospital Niño Jesús, Avenida Menéndez Pelayo, 65 , \\ E-28009 Madrid, Spain; Email: argentefen@teleline.es)
}

\begin{abstract}
Objective: The aim of this study was to follow auxological parameters and their relationship to serum growth hormone-binding protein (GHBP) and leptin levels in children with acute lymphoblastic leukemia (ALL).

Design and methods: In total, 26 prepubertal children with ALL were studied. We report these data at the time of the clinical diagnosis $(n=26)$ and at $6(n=21), 12(n=21), 18(n=21), 24(n=20), 30$ $(n=16)$ and 36 months $(n=16)$ after beginning treatment.

Results: Serum GHBP levels decreased during the first 18 months and returned to normal when therapy was withdrawn. Height SDS increased at 24 months after diagnosis. Weight and the upper arm circumference had increased 6 months after chemotherapy withdrawal, whereas tricipital and subscapular skinfolds had increased both at 6 months after diagnosis and 6 months after therapy had stopped. Therefore, the tendency to become overweight is both an early and a late side-effect of anti-leukemia therapy. A significant positive correlation was found between serum leptin levels and every nutritional anthropometric parameter, with body mass index having the best relationship. However, serum GHBP levels were only correlated with BMI at the end of the study. No correlation was found between leptin and GHBP.

Conclusions: In children with ALL, linear growth is compromised during the acute phase of their illness and therapy; this is probably secondary to a state of partial and transient GH insensitivity. These patients tend to become obese after therapy withdrawal, with leptin being an excellent nutritional marker.
\end{abstract}

European Journal of Endocrinology 143 243-250

\section{Introduction}

Acute lymphoblastic leukemia (ALL) is the most common type of leukemia in children and accounts for one-quarter of all childhood cancers (1). Improved survival rates have resulted in increased attention being focused on late side-effects, which include recurring neoplasms, cardiotoxicity, neuropsychologic dysfunction and endocrinologic sequelae including growth impairment, precocious puberty, gonadal dysfunction and obesity $(2-4)$.

Both leukemia and its treatment can have a severe catabolic effect on children. Even when well and in remission, children with cancer are severely catabolic (5) and consequently the growth hormone/insulin-like growth factor (GH-IGF) axis is altered. Situations of increased protein catabolism or net protein breakdown result in insensitivity or resistance to $\mathrm{GH}$, as reflected by reduced circulating levels of IGF-I and growth hormone-binding protein (GHBP) and growth failure. Furthermore, malnutrition, which often occurs in children with cancer, could contribute to these endocrine changes $(6,7)$.

The adverse effects of therapy on weight gain in children with ALL is, however, less well documented. Obesity is not only associated with elevated blood pressure, hyperlipidemia, altered glucose metabolism and cardiovascular disease, but also affects the psychosocial adaptation of long-term survivors $(8,9)$. Leptin, a product of the $o b$ gene, regulates appetite and energy expenditure, but it may also have a more general role in the regulation of growth and sexual maturation (10). Several large studies in children have shown a strong correlation between serum leptin levels and adiposity 
as determined by body mass index (BMI) (10-12). Furthermore, total deficiency in leptin or resistance to this protein can cause severe obesity (12).

The aims of the present study were: (i) to analyze the evolution of auxological data in ALL patients during 2 years of therapy and 1 year after treatment withdrawal; (ii) to determine the serum levels of GHBP and leptin in these children; and (iii) to study possible correlations between these parameters.

\section{Subjects and methods}

\section{Subjects}

The study population included 26 prepubertal children with ALL without central nervous system (CNS) involvement (19 males and 7 females) and 37 healthy age-matched children (24 males and 13 females). Diagnosis of ALL was made according to the definitions and requirements defined by the German cooperative group BFM (Berlin-Frankfurt-Münster) (13). The patients were studied at seven different points: at diagnosis $(n=26)$, and at $6(n=21), 12(n=21), 18$ $(n=21), 24 \quad(n=20), 30 \quad(n=16)$ and 36 months $(n=16)$ after the start of therapy. The distribution by risk groups was as follows: 11 standard-risk, 11 intermediate-risk and 4 high-risk. During the study period, 6 patients died (2 intermediate-risk and 4 high-risk). The therapy employed followed the BFM-90 protocol.

All normal subjects were referred to the Division of Endocrinology for suspected endocrine abnormalities and were found to be normal, each having a height and a BMI between -1 and 1 s.D. according to Spanish standards (14). This study has been approved by the Ethics Committee of the Hospital Niño Jesús.

\section{The BFM-90 treatment schedule}

Protocol I. This therapeutic phase was common for all risk groups. The duration was 64 days. The drugs used were prednisone, vincristine, daunorubicine, L-asparaginase, cyclophosphamide, arabinoside-C, 6-mercaptopurine and intrathecal methotrexate.

Protocol M. The duration was 56 days. The drugs used were 6-mercaptopurine, L-asparaginase, high-dose methotrexate and intrathecal methotrexate.

Protocol II. The duration was 49 days and the drugs employed included dexamethasone, vincristine, adriamicine, L-asparaginase, cyclophosphamide, arabinoside-C, 6-thioguanine and intrathecal methotrexate.

High-risk blocks. Therapeutic blocks 1, 2 and 3 lasted 6 days each. They were administered consecutively, with intervals of 15 days. They were repeated three times each.

Maintenance therapy. In this period, daily oral 6-mercaptopurine $\left(50 \mathrm{mg} / \mathrm{m}^{2}\right)$ and weekly oral methotrexate $\left(20 \mathrm{mg} / \mathrm{m}^{2}\right)$ were used to complete 24 months from the beginning of the therapy.

Prophylactic cranial irradiation. Cranial irradiation was only administered to patients of the intermediate-risk and high-risk groups. This was applied in eight fractions delivered over two weeks to reach a total dose of $12 \mathrm{~Gy}$.

Auxology At all study points we measured height, weight, BMI, tricipital skinfold (TS), subscapular skinfold (SS) and the upper arm circumference (UAC). The BMI was calculated as weight (kilograms)/height (meters $)^{2}$. The s.D. scores were based upon normative data from Spanish children (14).

\section{Biochemical measurements}

In all subjects, blood samples were drawn in conditions of fasting between 08.00 and $10.00 \mathrm{~h}$. Serum leptin levels were determined by radioimmunoassay (Linco, Inc, St Charles, MO, USA). The intra- and interassay coefficients of variation were 4.2 and $7.8 \%$ respectively. Serum GHBP levels were determined in duplicate by a monoclonal assay (Endocrine Sciences, Calabasas Hills, CA, USA) by incubating patient serum with excess radiolabeled human $\mathrm{GH}(\mathrm{hGH})$ and the monoclonal antibody Mo Ab 263. The GH receptor binds to this antibody and to labeled hGH to form a trimolecular complex (anti-GH receptor/GHBP/ ${ }^{125} \mathrm{I}-\mathrm{hGH}$ ). The intraand interassay coefficients of variation were 5.6 and $9.5 \%$ respectively.

\section{Statistics}

All data are reported as the mean \pm S.E.M. Changes in the different parameters were assessed for seven periods, as follows: at diagnosis, and at $6,12,18,24$, 30 and 36 months after the start of therapy. The significance of these changes was analyzed by the Wilcoxon signed-rank test. Analyses were performed by one-way analysis of variance (ANOVA), followed by Scheffe's F test. Correlations were performed using simple regression analyses. $P<0.05$ was chosen as the level of significance.

\section{Results}

\section{Anthropometric parameters}

There were no significant differences in anthropometric or biochemical parameters between the different treatment protocols. Hence, all data are reported together. The mean age at diagnosis for the 26 patients with ALL was 5.12 years (range: $1.66-10.0$ years) and the mean age at the end of the study was 7.09 years (range: 5.5-9.0 years). The auxological data of patients with ALL at diagnosis and during the first 36 months of therapy are shown in Table 1. A significant increase in mean height S.D. at the end of therapy was found 
Table 1 Auxological data SD scores (height, weight, TS, SS and UAC) in children with ALL over time

\begin{tabular}{|c|c|c|c|c|c|c|c|}
\hline \multirow[b]{2}{*}{ Parameter } & \multicolumn{7}{|c|}{ Time } \\
\hline & $\begin{array}{c}D x^{*} \\
n=26\end{array}$ & $\begin{array}{c}6 \mathrm{m \dagger} \\
n=21\end{array}$ & $\begin{array}{c}12 \mathrm{~m} \\
n=21\end{array}$ & $\begin{array}{c}18 m \\
n=21\end{array}$ & $\begin{array}{l}24 \mathrm{~m} \\
n=20\end{array}$ & $\begin{array}{c}30 \mathrm{~m} \\
n=16\end{array}$ & $\begin{array}{c}36 \mathrm{~m} \\
n=16\end{array}$ \\
\hline \multicolumn{8}{|l|}{ Height } \\
\hline $\begin{array}{l}\text { Mean } \pm \text { S.E.M. } \\
\text { Range }\end{array}$ & $\begin{array}{c}0.55 \pm 0.19 \\
-0.99-2.73\end{array}$ & $\begin{array}{c}0.40 \pm 0.19 \\
-0.96-1.9\end{array}$ & $\begin{array}{c}0.71 \pm 0.22 \\
-0.92-2.57\end{array}$ & $\begin{array}{c}0.78 \pm 0.20 \\
-0.77-2.18\end{array}$ & $\begin{array}{c}0.97 \pm 0.21 \\
-0.64-2.2\end{array}$ & $\begin{array}{r}1.02 \pm 0.22 \\
-0.64-2.68\end{array}$ & $\begin{array}{r}1.03 \pm 0.20 \\
-0.34-2.33\end{array}$ \\
\hline \multicolumn{8}{|l|}{ Weight } \\
\hline $\begin{array}{l}\text { Mean } \pm \text { S.E.M. } \\
\text { Range }\end{array}$ & $\begin{array}{c}0.79 \pm 0.20 \\
-0.85-2.28\end{array}$ & $\begin{array}{c}1.10 \pm 0.24 \\
-0.15-2.27\end{array}$ & $\begin{array}{c}0.86 \pm 0.27 \\
-0.45-2.16\end{array}$ & $\begin{array}{c}0.78 \pm 0.26 \\
-0.45-1.8\end{array}$ & $\begin{array}{c}1.26 \pm 0.33 \\
0.21-3.28\end{array}$ & $\begin{array}{c}1.51 \pm 0.26 \\
0.49-3.76\end{array}$ & $\begin{array}{r}1.50 \pm 0.27 \\
0.82-3.32\end{array}$ \\
\hline \multicolumn{8}{|l|}{ TS } \\
\hline $\begin{array}{l}\text { Mean } \pm \text { S.E.M. } \\
\text { Range }\end{array}$ & $\begin{array}{c}0.34 \pm 0.23 \\
-1.27-1.30\end{array}$ & $\begin{array}{c}1.36 \pm 0.38 \\
0.39-3.22\end{array}$ & $\begin{array}{c}0.78 \pm 0.26 \\
-0.23-2.71\end{array}$ & $\begin{array}{c}0.57 \pm 0.23 \\
-0.53-2.25\end{array}$ & $\begin{array}{c}1.04 \pm 0.36 \\
0.16-3.17\end{array}$ & $\begin{array}{c}1.37 \pm 0.24 \\
0.72-2.34\end{array}$ & $\begin{array}{c}1.78 \pm 0.20 \\
0.87-3.07\end{array}$ \\
\hline \multicolumn{8}{|l|}{ SS } \\
\hline $\begin{array}{l}\text { Mean } \pm \text { S.E.M. } \\
\text { Range }\end{array}$ & $\begin{array}{c}1.25 \pm 0.39 \\
-0.92-3.44\end{array}$ & $\begin{array}{c}1.90 \pm 0.32 \\
0.82-4.00\end{array}$ & $\begin{array}{l}0.72 \pm 0.33 \\
-1.3-2.8\end{array}$ & $\begin{array}{c}0.86 \pm 0.32 \\
-0.58-2.93\end{array}$ & $\begin{array}{c}1.60 \pm 0.45 \\
0.13-3.96\end{array}$ & $\begin{array}{l}1.88 \pm 0.38 \\
0.42-3.6\end{array}$ & $\begin{array}{r}1.54 \pm 0.28 \\
0.87-2.73\end{array}$ \\
\hline \multicolumn{8}{|l|}{ UAC } \\
\hline $\begin{array}{l}\text { Mean } \pm \text { S.E.M. } \\
\text { Range }\end{array}$ & $\begin{array}{c}-0.30 \pm 0.24 \\
-1.98-1.04\end{array}$ & $\begin{array}{c}-0.18 \pm 0.23 \\
-1.43-1.70\end{array}$ & $\begin{array}{c}-0.27 \pm 0.25 \\
-1.43-1.63\end{array}$ & $\begin{array}{c}0.05 \pm 0.28 \\
-1.23-1.89\end{array}$ & $\begin{array}{l}0.40 \pm 0.36 \\
-0.5-1.3\end{array}$ & $\begin{array}{c}0.62 \pm 0.15 \\
0.21-1.74\end{array}$ & $\begin{array}{r}0.97 \pm 0.27 \\
0.23-2.05\end{array}$ \\
\hline
\end{tabular}

${ }^{\star}$ Dx, at diagnosis; $† \mathrm{~m}$, months.

(Fig. 1A; ANOVA: $P<0.05$ ). These patients had significantly increased skinfolds (tricipital and subscapular; ANOVA: $P<0.05) 6$ months after diagnosis and 6 months after treatment suspension (Table 1; Fig. 1C and 1). However, weight and UAC only increased 6 months after chemotherapy withdrawal (Fig. 1B and 1; ANOVA: $P<0.05)$.

\section{Biochemical results}

Mean \pm s.E.M. serum GHBP and leptin levels are expressed in Table 2. Serum GHBP levels (Fig. 2A) were significantly lower in patients with ALL at diagnosis compared with controls and did not change during the first 18 months, but returned to normal values 24 months after diagnosis (ANOVA: $P<0.05$ ). Serum leptin levels (Fig. 2B) were significantly elevated in these patients 6 months after diagnosis and 1 year after chemotherapy withdrawal (ANOVA: $P<0.05$ ).

There were no differences between boys and girls with regard to the different risk groups or the parameters analyzed at the time of diagnosis or during the study period.

\section{Regression analyses}

The results of all regression analyses performed are represented in Table 3. A significant positive correlation was found between serum leptin levels and every nutritional anthropometric parameter (weight, BMI, TSs, SSs and UAC), with BMI having the best relationship (Fig. 3). Serum GHBP levels correlated significantly with weight and BMI only at the end of the study. Serum GHBP levels correlated with height at various times throughout the study, with the strongest correlation ocurring after 1 year without therapy. No correlation was found between GHBP and leptin.

\section{Discussion}

Acute lymphoblastic leukemia is the most frequent childhood malignancy (1). Because of the increasing number of long-term survivors in recent decades, it is important to determine the late side-effects of this disease and its treatment, including growth failure and obesity. In the present study we report auxological data and serum levels of GHBP and leptin in a group of prepubertal children with ALL at the time of clinical diagnosis and at $6,12,18,24,30$ and 36 months after the start of therapy. As this is the first reported study in which these parameters have been measured simultaneously in the same population at seven stages of disease evolution, we also analyzed the correlations between these variables.

Growth retardation is a common finding in children successfully treated for ALL. Various factors have been cited as contributing to this growth retardation, including the catabolic state due to the disease itself, infections, reduced energy intake, chemotherapy and cranial irradiation (15). Unfortunately, the data on growth after therapy for childhood acute lymphoblastic leukemia are conflicting. It is well known that cranial radiotherapy may produce $\mathrm{GH}$ deficiency (16, 17); however, the effect of the illness itself and the chemotherapy on linear growth is less well understood. Both leukemia and its treatment can have severe catabolic effects in children. Even when well and in remission, children with cancer are severely catabolic, 
(A)
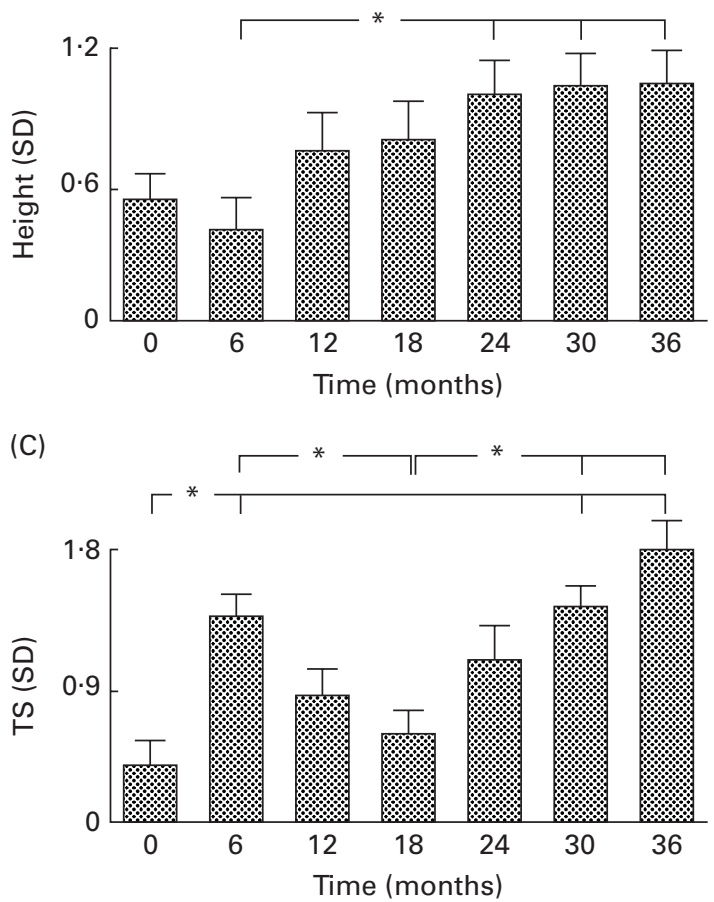

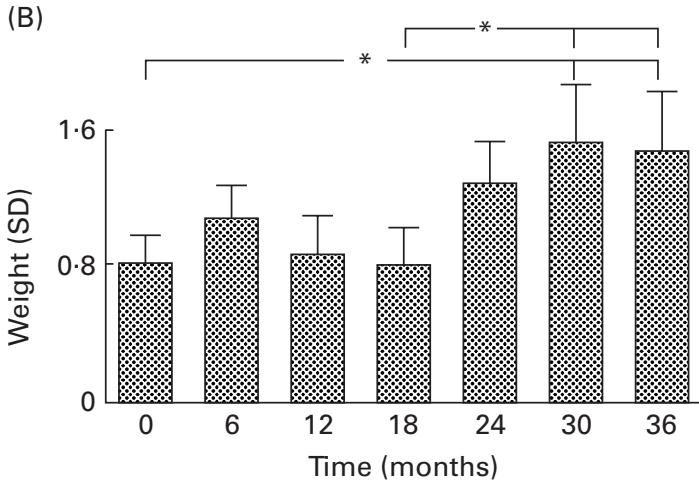

(D)

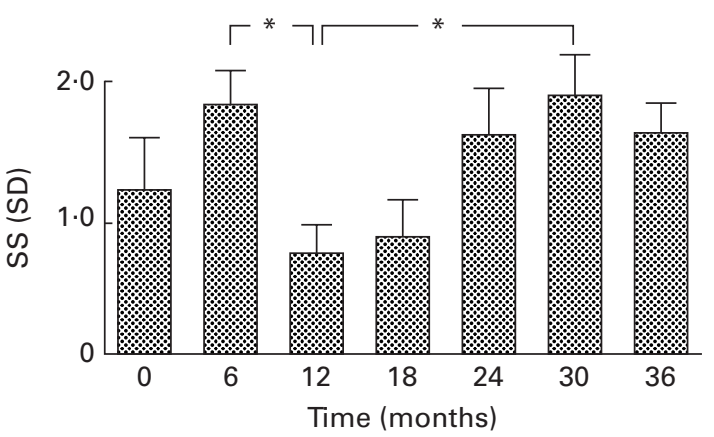

(E)

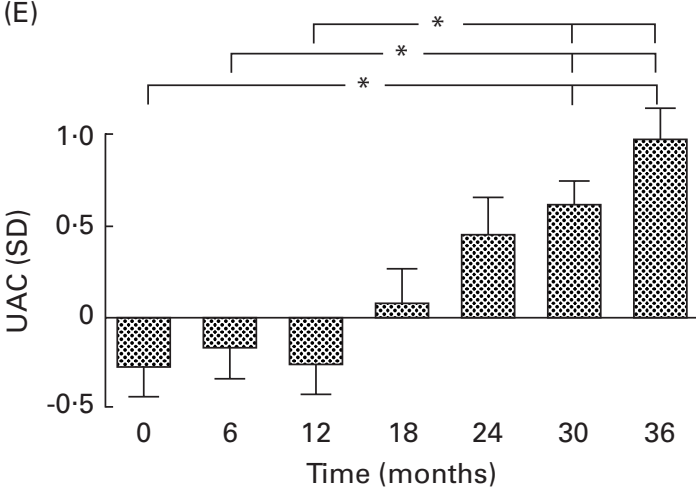

Figure 1 Mean ( \pm S.E.M.) SD score for height (A), weight (B), TS (C), SS (D) and UAC (E) of patients with ALL from diagnosis until 3 years after diagnosis (*ANOVA, $P<0.05)$.

as indicated by an increase in protein breakdown and, to a lesser degree, protein synthesis (5). In conditions that have malnutrition and net protein catabolism in common, a GH-resistant state is often present (6).
The growth-promoting and metabolic actions of $\mathrm{GH}$ are mediated by specific $\mathrm{GH}$ receptors (GHRs) on the surface of target cells. The absence of or reduction in functional GHRs results in GH insensitivity and growth

Table 2 Mean \pm S.E.M. serum values for GHBP (pmol/l) and leptin (ng/ml) in controls (C) and patients with ALL over time. Abbreviations are as given in Table 1.

\begin{tabular}{|c|c|c|c|c|c|c|c|c|}
\hline Parameter & $\begin{array}{c}\mathbf{C} \\
n=37\end{array}$ & $\begin{array}{c}\text { Dx } \\
n=26\end{array}$ & $\begin{array}{c}6 \mathbf{m} \\
n=21\end{array}$ & $\begin{array}{c}12 \mathbf{m} \\
n=21\end{array}$ & $\begin{array}{c}18 \mathbf{m} \\
n=21\end{array}$ & $\begin{array}{c}24 \mathbf{m} \\
n=20\end{array}$ & $\begin{array}{c}30 \mathrm{~m} \\
n=16\end{array}$ & $\begin{array}{c}36 \mathbf{m} \\
n=16\end{array}$ \\
\hline $\begin{array}{l}\text { GHBP } \\
\text { Leptin }\end{array}$ & $\begin{array}{r}1166 \pm 65 \\
5.1 \pm 0.5\end{array}$ & $\begin{array}{c}720 \pm 72 \\
6.2 \pm 1.2\end{array}$ & $\begin{array}{c}912 \pm 72 \\
8.8 \pm 1.4\end{array}$ & $\begin{array}{c}962 \pm 84 \\
5.6 \pm 1.2\end{array}$ & $\begin{array}{c}927 \pm 76 \\
5.7 \pm 0.9\end{array}$ & $\begin{array}{r}1056 \pm 79 \\
6.0 \pm 1.2\end{array}$ & $\begin{array}{r}1222 \pm 58 \\
5.6 \pm 0.7\end{array}$ & $\begin{array}{r}1108 \pm 98 \\
10.1 \pm 0.7\end{array}$ \\
\hline
\end{tabular}




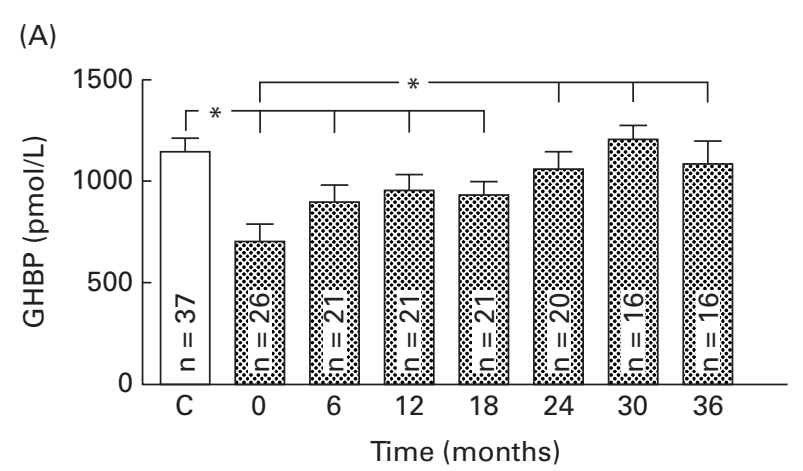

(B)

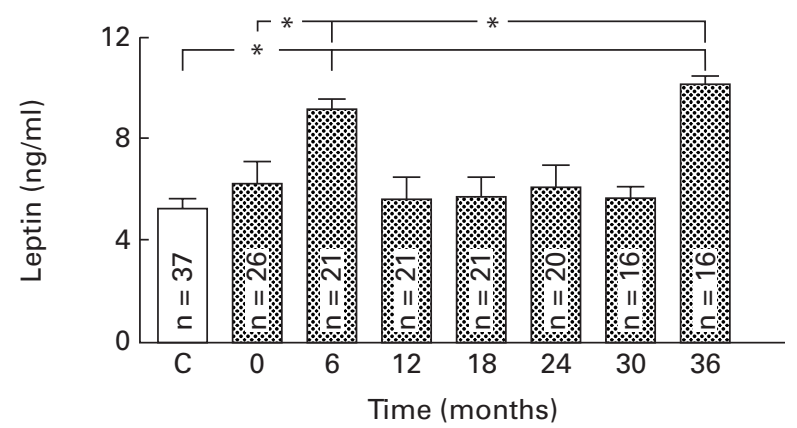

Figure 2 Schematic representation of the mean \pm S.E.M. serum levels of GHBP (A) and leptin (B) in controls (C) and in patients with ALL over time ( ${ }^{\star}$ ANOVA, $\left.P<0.05\right)$.

failure (18). It is difficult to study GHR abundance and function directly in humans; however, several observations indicate a direct relationship between GHBP and GHR levels. Both GHBP and the GHR are products of the GHR gene (10).

Our data support previous observations that linear growth is compromised during initial chemotherapy but is then followed by 'catch-up' growth $(19,20)$. Such gains became significant by the 24th month of therapy. We cannot establish the exact cause of the decrease in growth rate during the initial treatment period, but chemotherapy must be important in this respect. 'Catch-up' growth occurred during maintenance therapy, when the treatment was less aggressive than in the first therapeutic phase. In our study, no difference was detected between irradiated and nonirradiated children during the 3 years after diagnosis; this suggests that cranial irradiation, at a dose of $12 \mathrm{~Gy}$, does not play a major role in modulating height SD scores.

The results of the present study are consistent with those of previous reports (21) and demonstrate clearly that, at diagnosis, serum GHBP levels in ALL patients are significantly lower than control values. This is comparable to that which is observed in malnutrition and other catabolic conditions such as trauma, sepsis, surgery and organ failure (6). Serum GHBP levels were low during the first 18 months and then returned to normal values when therapy was withdrawn. Furthermore, serum IGF-I levels were significantly reduced until 1 year after therapy withdrawal and growth velocity increased significantly during the same period (22). This partial and transient GH insensitivity, as suggested by the low GHBP and IGF-I levels, induced by the acute phase of illness and therapy may explain the growth retardation observed in these patients. This possible state of GH-resistance must play an important role, as 'catch-up' growth does not occur until GHBP levels are normalized. Indeed, at the end of study there was a very strong correlation between GHBP and height.

Some investigators have reported that body composition plays a key role in the regulation of GHBP levels, there being a positive correlation between serum GHBP levels and BMI in healthy children and adults (23). However, we did not find this correlation in patients with anorexia nervosa (24), an extreme catabolic state. In the present study of children with ALL, serum GHBP

Table 3 Linear correlation $(P<0.05)$ between GHBP and leptin and the nutritional anthropometric parameters studied (height, weight, BMI, TS, SS and UAC) at diagnosis, and at 6, 24 and 36 months after the start of therapy.

\begin{tabular}{|c|c|c|c|c|c|c|}
\hline Parameter & Height & Weight & BMI & TS & ss & UAC \\
\hline \multicolumn{7}{|l|}{ At diagnosis } \\
\hline GHBP & 0.36 & 0.32 & $\mathrm{NS}^{*}$ & NS & NS & NS \\
\hline Leptin & NS & 0.42 & 0.59 & 0.49 & 0.26 & 0.57 \\
\hline \multicolumn{7}{|l|}{ At 6 months } \\
\hline GHBP & NS & NS & NS & NS & NS & NS \\
\hline Leptin & NS & 0.64 & 0.72 & 0.64 & 0.63 & 0.78 \\
\hline \multicolumn{7}{|l|}{ At 24 months } \\
\hline GHBP & 0.41 & NS & NS & NS & NS & NS \\
\hline Leptin & NS & 0.81 & 0.91 & 0.73 & 0.84 & 0.75 \\
\hline \multicolumn{7}{|l|}{ At 36 months } \\
\hline GHBP & 0.97 & 0.72 & 0.44 & NS & NS & NS \\
\hline Leptin & NS & 0.77 & 0.82 & 0.58 & 0.71 & 0.60 \\
\hline
\end{tabular}

${ }^{*} \mathrm{NS}$, not significant. 


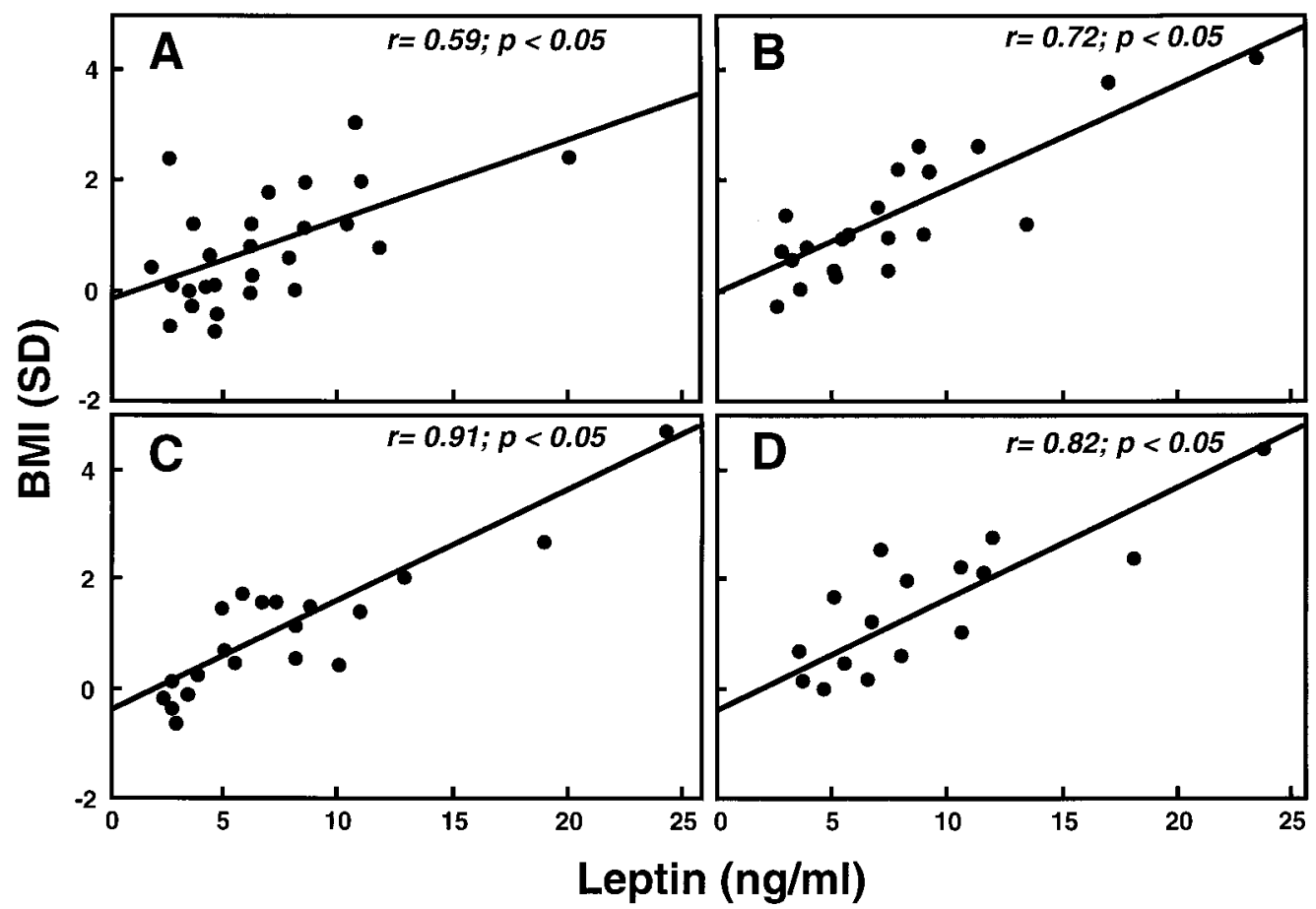

Figure 3 Linear correlation between BMI and serum leptin levels in children with ALL at diagnosis (A), 6 (B), 24 (C) and 36 months (D) after the start of therapy.

levels showed a strong correlation with BMI, which is similar to the situation in normal subjects.

The children in our study had a tendency to gain weight after the termination of therapy. The frequency and pattern of obesity in survivors of ALL is less well documented than the effect of this disease on linear growth. Nevertheless, it is calculated that nearly half of the long-term survivors of childhood leukemia are overweight $(25,26)$. Endocrine disorders causing blunted growth, e.g. hypothyroidism, hypercortisolism and $\mathrm{GH}$ deficiency, are often associated with obesity (27). However, in ALL patients the etiology is almost certainly multifactorial. Factors such as cranial irradiation, chemotherapy, treatment with corticosteroids, lack of physical exercise and poor dietary habits probably contribute to the excess weight gain in these patients (26). Cranial irradiation may cause damage to the hypothalamic-pituitary axis, affecting the secretion of GH and inducing a neurosecretory dysfunction, resulting in a decrease in growth and lipolysis and possibly obesity $(8,27)$. Excess weight gain during and after treatment for leukemia is also seen in children treated only with cytotoxic drugs and corticosteroids. Several investigators have shown that the use of corticosteroid therapy, especially with dexametasone, has an important effect on weight $(8,27,28)$.

In the present study, evolution of the nutritional anthropometic parameters varied. Weight and UAC only increased 6 months after chemotherapy withdrawal, whereas TSs and SSs were increased both at 6 months after diagnosis, when height was significantly reduced, and at 6 months after therapy was stopped. Corticosteroids, which were used in the first 6 months after diagnosis, could explain the rise in the TSs and SSs. Therefore, the increase in weight observed during and after chemotherapy withdrawal in the present study and by others $(4,26)$ suggests an effect of chemotherapy on body composition, although the mechanism is unknown.

We confirm previous data $(8,27)$ showing no difference between irradiated and non-irradiated children or between boys and girls during the 3 years after diagnosis. This suggests that neither cranial irradiation at a dose of $12 \mathrm{~Gy}$ nor gender plays a major role in bodyweight evolution in these patients. This is in contrast to the data of Odame et al. (4), who conclude that obesity in patients treated for ALL is more pronounced in girls than in boys, and that cranial irradiation is an important factor. However, it will be some time before sufficient data can be accrued to assess the effect of these regimens on adult body weight.

Leptin, which is produced in adipose tissue, acts as a hormonal feedback signal to regulate fat-cell size through hypothalamic mechanisms controlling food intake and metabolic rate (29-31). In normal pediatric subjects, leptin levels are highly correlated with the BMI, but this is not the case in patients with eating disorders where the BMI is either significantly elevated 
or reduced (11). The fact that serum leptin levels are elevated in obese patients suggests a leptin resistance syndrome. Whether this is due to a reduction in leptin receptor number or responsivity or to a decrease in leptin bioactivity remains to be determined (12).

Recently it has been shown that cytokines, such as tumor-necrosis factor $\alpha(\mathrm{TNF} \alpha)$, can increase leptin levels and perhaps participate in loss of appetite and wasting in chronic disease (32). In our study, serum leptin levels were elevated in ALL patients 6 months after diagnosis and 1 year after chemotherapy withdrawal. The rise in serum leptin levels at 6 months after diagnosis could be secondary to the rise in body fat (as indicated by the increase in skinfolds) and the use of corticosteroids, which stimulate leptin synthesis (33). We found no differences in serum leptin levels between girls and boys or between irradiated and non-irradiated patients, whereas in Birkebaek's study, serum leptin was significantly higher in patients treated with cranial irradiation compared with the non-irradiated group (34).

A significant positive correlation was found between serum leptin levels and every anthropometric parameter (weight, BMI, TSs, SSs and UAC), with BMI having the strongest relationship. These findings are in agreement with the retrospective study of Birkebaek et al. (34). Furthermore, the correlation between leptin and GHBP that exists in normal subjects (10) is not found in prepubertal ALL children, suggesting an influence from other factors, such as cytokines, that are present in catabolic states $(18,32)$.

In summary, this study demonstrates that in prepubertal children with ALL, linear growth is compromised during the acute phase of illness and therapy. This is probably secondary to a state of partial and transient GH insensitivity, as indicated by low GHBP levels. Furthermore, catch-up growth occurs when GHBP levels normalize. These patients have a tendency to be overweight after therapy withdrawal and leptin seems to be an excellent nutritional marker as it shows good correlation with anthropometric parameters and was modified during those periods when changes in metabolism might be expected, i.e. at the beginning of treatment and upon its withdrawal.

\section{Acknowledgements}

The authors thank Dr Julie A Chowen for the critical review of the manuscript. We wish to thank to NIDDK's National Hormone and Pituitary Program for the gift of growth hormone for iodination. This work was supported by the Fundación Endocrinología y Nutrición.

\section{References}

1 Gurney JC, Severson RK, Davis S \& Robison LL. Incidence of cancer in children in the United States. Cancer 199575 2186-2195.
2 Chessells JM, Bailey C \& Richards SM, for the Medical Research Council Working Party on Childhood leukaemia. Intensification of treatment and survival in children with lymphoblastic leukaemia: results of UK Medical Research Council trial UKALL X. Lancet 1995345 143-148.

3 Conter V, Aricò M \& Valsecchi MG, for the Associazione Italiana di Ematologia ed Oncologia Pediatrica. Extended intrathecal methotrexate may replace cranial irradiation for prevention of CNS relapse in children with intermediate-risk acute lymphoblastic leukemia treated with Berlin-Frankfurt-Münster-based intensive chemotherapy. Journal of Clinical Oncology 199513 2497-2502.

4 Odame I, Reilly JJ, Gibson BES \& Donaldson MDC. Patterns of obesity in boys and girls after treatment for acute lymphoblastic leukaemia. Archives of Disease in Childhood 199471 147-149.

5 Attard-Montalto SP, Camacho-Hubner C \& Cotterill AM. Changes in protein turnover, IGF-I and IGF binding proteins in children with cancer. Acta Paediatrica 199887 54-60.

6 Ross RJM \& Chew SL. Acquired growth hormone resistance. European Journal of Endocrinology 1995132 655-660.

7 Crofton PM, Ahmed SF, Wade IC, Stephen R, Elmlinger MW, Ranke MB et al. Effects of intensive chemotherapy on bone and collagen turnover and the growth hormone axis in children with acute lymphoblastic leukemia. Journal of Clinical Endocrinology and Metabolism 199883 3121-3129.

8 Van Dongen-Melman JEWM, Hokken-Koelega ACS, Hählen K, De Groot A, Tromp CG \& Egeler RM. Obesity after successful treatment of acute lymphoblastic leukemia in childhood. Pediatric Research 199538 86-90.

9 Müller HL, Klinkhammer-Schalke M \& Kühl J. Final height and weight of long-term survivors of childhood malignancies. Experimental and Clinical Endocrinology and Diabetes 1998106 135-139.

10 Bjarnason R, Boguszewski M, Dahlgren J, Gelander L, Kriström B, Rosberg $\mathrm{S}$ et al. Leptin levels are strongly correlated with those of GH-binding protein in prepubertal children. European Journal of Endocrinology $199713768-73$.

11 Rogol AD. Editorial: Leptin and puberty. Journal of Clinical Endocrinology and Metabolism 199883 1089-1090.

12 Bray GA \& York DA. Leptin and clinical medicine: a new piece in the puzzle of obesity. Journal of Clinical Endocrinology and Metabolism 199782 2771-2776.

13 Van der Does-Van den Berg A, Bartram CR \& Basso G. Minimal requirements for the diagnosis, classification, and evaluation of the treatment of childhood acute lymphoblastic leukemia (ALL) in the 'BFM Family' cooperative group. Medical Pediatric Oncology $199220497-505$.

14 Hernández M, Castellet J, Narvaíza JL, Rincón JM, Ruiz I, Sánchez E et al. Curvas y Tablas de Crecimiento. Eds M Hernández \& F Fundación. Orbegozo. Madrid: Editorial Garsi 1988.

15 Márky I, Mellander L, Lannering B \& Albertsson-Wikland K. A longitudinal study of growth and growth hormone secretion in children during treatment for acute lymphoblastic leukemia. Medical Pediatric Oncology 199119 258-264.

16 Brauner R \& Rappaport R. Pituitary hormone secretion and growth after cranial irradiation. Therapeutic consequences. In Hormonal Regulation of Growth, pp 245-253. Eds H Frish \& MO Thorner. New York: Raven Press, 1989.

17 Shalet SM. Growth in the irradiated child. In Two Decades of Experience in Growth, pp 227-237. Eds M Pombo \& RG Rosenfeld. New York: Raven Press, 1993.

18 Hermansson M, Wickelgren RB, Hammarqvist F, Bjarnason R, Wennström I, Wernerman S et al. Measurement of human growth hormone receptor messenger ribonucleic acid by a quantitative polymerase chain reaction-based assay: demonstration of reduced expression after elective surgery. Journal of Clinical Endocrinology and Metabolism 199782 421-428.

19 Hokken-Koelega ACS, Van Doorn JWD, Hählen K, Stijnen T, De Muinck Keizer-Schrama SMPF \& Drop SLS. Long-term effects of treatment for acute lymphoblastic leukemia with and without 
cranial irradiation on growth and puberty; a comparative study. Pediatric Research 199333 577-582.

20 Caruso-Nicoletti M, Mancuso M, Spadaro G, Dibenedetto SP Dicataldo A \& Schiliró G. Growth and growth hormone in children during and after therapy for acute lymphoblastic leukaemia. European Journal of Pediatrics 1993152 730-733.

21 Nivot S, Benelli C, Clot JP, Saucet C, Adan L, Souberbielle JC et al. Nonparallel changes of growth hormone $(\mathrm{GH})$ and insulinlike growth factor-I, insulin-like growth factor binding protein-3 and GH-binding protein, after craniospinal irradiation and chemotherapy. Journal of Clinical Endocrinology and Metabolism 199478 597-601.

22 Argüelles B, Barrios V, Pozo J, Madero L \& Argente J. Longitudina study of the ternary complex of human insulin-like growth factors (IGFs) in children with acute lymphoblastic leukemia. Hormone Research 199850 (Suppl 3) 30 (Abstract).

23 Martha PM, Reiter EO, Dávila N, Shaw MA, Holcombe JH \& Baumann G. The role of body mass in the response to growth hormone therapy. Journal of Clinical Endocrinology and Metabolism 199275 1470-1473.

24 Argente J, Caballo N, Barrios V, Muñoz MT, Pozo J, Chowen JA et al. Multiple endocrine abnormalities of the growth hormone and insulin-like growth factor axis in patients with anorexia nervosa: effect of short and long-term weight recuperation. Journal of Clinical Endocrinology and Metabolism 199782 2084-2092.

25 Didi M, Didcock E, Davies HA, Ogilvy-Stuart AL, Wales JKH \& Shalet SM. High incidence of obesity in young adults after treatment of acute lymphoblastic leukemia in childhood. Journal of Pediatrics 1995125 63-67.

26 Davies HA, Didcock E, Didi M, Ogilvy-Stuart AL, Wales JKH \& Shalet SM. Growth, puberty and obesity after treatment for leukemia. Acta Paediatrica 1995411 (Suppl) 45-50.
27 Groot-Loonen JJ, Otten BJ, van't Hof MA, Lippens RJJ \& Stoelinga GBA. Influence of treatment modalities on body weight in acute lymphoblastic leukemia. Medical and Pediatric Oncology 199627 92-97.

28 Ahmed SF, Wallace WHB \& Kelnar CJH. An anthropometric study of children during intensive chemotherapy for acute lymphoblastic leukaemia. Hormone Research 199748 178-183.

29 Ahima RS, Prabakaran D, Mantzoros C, Ou D, Lowell B \& Mataros-Flier E. Role of leptin in the neuroendocrine response to fasting. Nature 1996382 250-252.

30 Rohner-Jeanrenaud F \& Jeanrenaud B. Obesity, leptin, and the brain. New England Journal of Medicine 1996334 324- 325.

31 Blum WF, Englaro P, Hanitsch S, Juul A, Hertel NT, Müller J et al. Plasma leptin levels in healthy children and adolescents: dependence on body mass index, body fat mass, gender, pubertal stage, and testosterone. Journal of Clinical Endocrinology and Metabolism 199782 2904-2910.

32 Zumbach MS, Boehme MWJ, Wahl P, Stremmel W, Ziegler R \& Nawroth PP. Tumor necrosis factor increases serum leptin levels in humans. Journal of Clinical Endocrinology and Metabolism 1997 82 4080-4082.

33 Yeste D, Gómez L, Potau N, Gussinyé M \& Carrascosa A. Leptina: implicaciones clínicas. Anales Españoles de Pediatría 1998111 (Suppl) 36- 42

34 Birkebaek NH, Fisker S, Clausen N, Tuovinen V, Sindet-Pedersen S \& Christiansen JS. Growth and endocrinological disorders up to 21 years after treatment for acute lymphoblastic leukemia in childhood. Medical Pediatric Oncology 199830 351-356.

Received 20 December 1999

Accepted 5 April 2000 